\title{
Nový typ bronzové jehlice ve Slezsku
}

\section{A new type of bronze pin in Silesia}

\section{Stanislav Stuchlík}

\begin{abstract}
Abstrakt
$\checkmark$ posledních letech objevili amatéři ve Slezsku pomocí detektoru tři nové bronzové jehlice. Jde o dosud neznámý typ dvoudílné jehlice s velkou dutou kulovitou hlavicí, která má na spodní straně dva nevelké otvory. Vzdálené obdoby pro ně známe z Francie, Švýcarska, Německa a ojediněle i z Čech. Jehlice ze Slezska jsou však, na rozdíl od zmíněných analogií, vždy dvojdílné a mají plechovou hlavici se dvěma nevelkými otvory na spodní straně. Všechny tři jehlice pocházejí z ojedinělých nálezů. Datovat je můžeme podle vzdálených obdob a na základě místa nálezu pouze rámcově do období popelnicových polí.
\end{abstract}

\section{Klíčová slova}

Bronzové jehlice, jehlice s dutou kulovitou hlavicí, doba popelnicových polí, Horní Slezsko, Dolní Slezsko

\begin{abstract}
In the past few years, amateur detectorists in Silesia discovered three new bronze pins. They represent a still unknown type of a two-part pin with large hollow spherical head with two small holes at its bottom. Remote analogies are known from France, Switzerland, Germany and sporadically from Bohemia as well. But only the finds from Silesia, unlike the above analogies, are always composed of two parts and have a sheet metal head with two small perforations at the bottom. All three pins are isolated finds. According to remote analogies and the finding places, we can date them only generally to the Urnfield Period.
\end{abstract}

\section{Keywords}

Bronze pins, pins with hollow spherical head, Urnfield Period, Upper Silesia, Lower Silesia 
Během posledních 20 let se v naších zemích výrazně rozšíríilo množství bronzové industrie díky činnosti zájemců o archeologii pracujících s pomocí detektorů. Jejich nálezy nemají však vždy stejný osud. Menší část památek se dostane do muzejních archeologických sbírek, zatímco další část artefaktů zůstane v soukromém držení, ale archeologové mají možnost nálezy aspoň dostatečně zdokumentovat a pro svou práci využít. Třetí skupinu představují předměty, které se stanou součástí privátních anonymních sbírek nebo dokonce zmizí v zahraničí a jsou tak pro bližší poznávání dávné minulosti našich zemí navždy ztraceny. $\mathrm{V}$ poslední době objevili amatéři pomocí detektoru v českém Slezsku dvě nové bronzové jehlice s dutou kulovitou hlavicí, které v naších zemích nebyly doposud zaznamenány. Jde o jehlici z Javorníka a o jehlici z výšinného sídliště v Krnově. Kromě toho se podobná jehlice s velkou kulovitou hlavicí našla opět pomocí detektoru na blíže neznámém nalezišti v Dolním Slezsku.

\section{Javorník (k. ú. Bílý Potok, okr. Jeseník)}

Na jaře 2015 nalezl J. Lednický z Jeseníku při pochůzce v polích jihovýchodně od obce Bílý Potok bronzovou jehlici. Předmět objevil nálezce pomocí detektoru kovů na parcele č. 1920, údajně v hloubce do $20 \mathrm{~cm}$ (Rychlý - Stuchlik 2016, 210, obr. 5).

\section{Popis:}

Dvoudílná bronzová jehlice s velkou dutou dvojkónickou plechovou hlavicí, která má na spodní části dva nevelké otvory (obr. 1:1). Hlavice je v horní části značně poškozená a vmáčknutá dovnitřr. Jehla má u hlavice kruhový průřez částečně zdobený šroubovitou rýhou, v dalším průběhu má jehla tvar obdélníku se zaoblenými hranami a u hrotu má opět kruhový průřez.
Jehla je ohnutá, na horní i dolní část jehlice má na užší straně jedné straně podélnou rýhu. Její celková délka (včetně hlavice) činí 105 mm, průměr hlavice $18 \mathrm{~mm}$ a maximální rozměry jehly $4 \times 2 \mathrm{~mm}$. Průměr otvorů se pohybuje mezi 1,5 až $2 \mathrm{~mm}$.

Uložení:

Vlastivědné muzeum Jesenicka v Jeseníku.

\section{Krnov (k. ú. Opavské Předměstí, okr. Bruntál)}

V prosinci 2014 nalezl L. Sosín na východním svahu výšinného naleziště Burgberk (Přední cvilínský kopec) bronzovou jehlici (Břiza - Sosín 2015). Někdy se tato lokalita v literatuře objevuje i pod názvem Burgberg. Jehlici objevil nálezce pomocí detektoru v hloubce do $15 \mathrm{~cm}$.

\section{Popis:}

Dvoudílná bronzová jehlice s velkou dutou kulovitou hlavicí zhotovenou z plechu. Hlavice má na vrcholu znatelný výčnělek, což je zřejmě zbytek jehly. Na největší výduti má dobře znatelnou hranu a na spodní straně dva nevelké otvory (obr. 1:2). Tenká jehla má v horní části čočkovitý průřez a v dolní polovině kruhový průřez. Jehlice je poněkud deformována a její celková délka (včetně hlavice) činí 132 mm, průměr hlavice $17 \mathrm{~mm}$, průměr jehly je $\mathrm{v}$ horní polovině $2,5 \times 2 \mathrm{~mm}$ a v dolní polovině $2 \mathrm{~mm}$. Průměr otvorů se pohybuje mezi 1,5 až $2,5 \mathrm{~mm}$.

\section{Uložení:}

Městské muzeum Krnov, př. č. 31/14. 


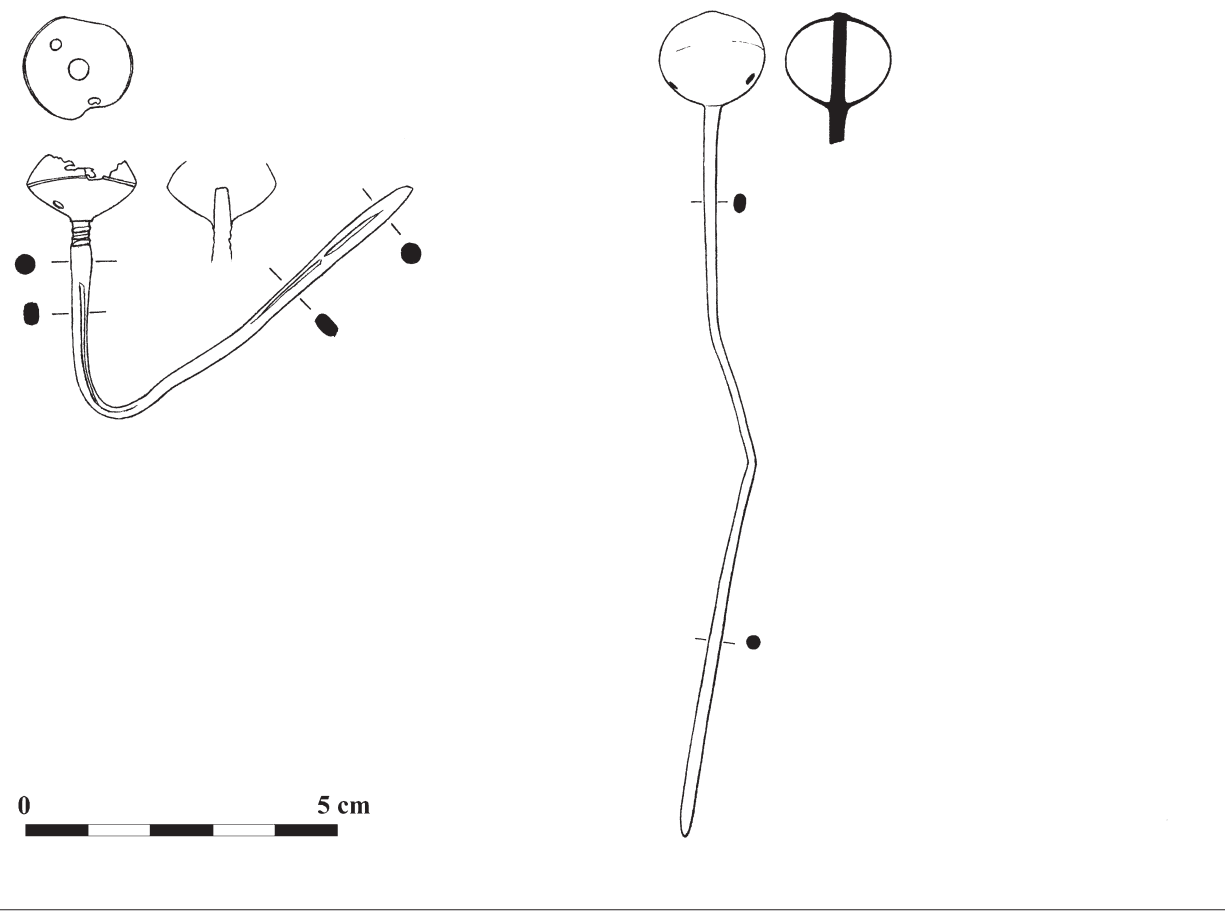

Obr. 1. Jehlice s dutou kulovitou hlavicí z Horního Slezska. 1 - Javorník, 2 - Krnov.

\section{Neznámé naleziště v Dolním Slezsku}

Na polských detektorářských stránkách byla vyobrazena bronzová jehlice s kulovitou hlavicí, která byla nalezena na blíže neurčeném místě, patrně v okolí obce Smolec západně od Wroclawi. ${ }^{1}$

\section{Popis:}

Pravděpodobně dvoudílná jehlice s velkou kulovitou dutou hlavicí s výraznou hranou na největší výduti (obr. 2b). Horní strana je zdobená skupinami rýžek a na spodní straně jsou dva nevelké otvory. Masivní jehla (obr. 2a) má na řezu tvar obdélníka se zaoblenými hranami, pouze hrot, který je obvodově rýhovaný, má kruhový průřez a samotná špice je patrně ulomená. Celkové délka jehlice (včetně hlavice) je přibližně $110 \mathrm{~mm}$ a průměr hlavice přibližně $19 \mathrm{~mm}$. $^{2}$

Místo uložení jehlice není známo.

\section{Rozbor}

Nově objevené jehlice s dutou kulovitou hlavicí představují ve Slezsku nový typ, který J. Ř́hovský při zpracování jehlic z Moravy a přilehlé části Rakouska nezaregistroval (říhouský 1979). Stejně tak se s nimi nesetkali při studiu jehlic z území Polska ani M. Gedl (1983) a R. Essen (1985). Značně vzdálenou obdobu pro 

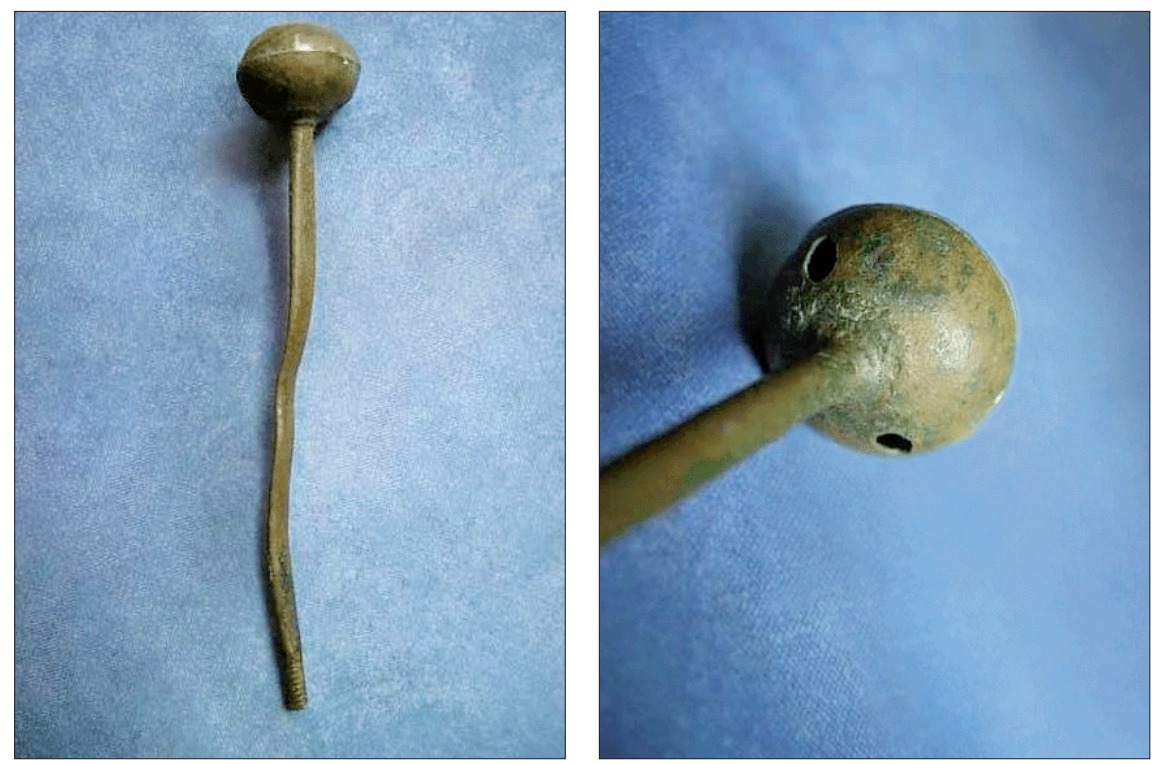

Obr. 2. Jehlice z neznámého naleziště v Dolním Slezsku v okolí Wrocławi.

naše exempláře představuje $\mathrm{v}$ českých zemích jednodílná jehlice s dutou hlavicí s pěti velkými otvory z depotu v Libákovicích v západních Čechách (obr. 4:1; Čtrnáct 1961; Čujanová-Jilková 1970, 44-45, Abb. 25:1,3-8), kterou O. Kytlicová zařadila do horizontu depotů Plzeň-Jíkalka, tedy na rozhraní stupňů $\mathrm{B}_{2} / \mathrm{D}$ (Kytlicová 2007, 277, Taf. 9B:6). Jde však o naprosto odlišný exemplár̆, který z typologického ani technologického hlediska nemá s našimi jehlicemi nic společného. Jinou, opět jen náhodnou podobnost vykazuje i několik starobronzových jehlic $\mathrm{s}$ kulovitou a šikmo provrtanou hlavicí z Německa a Rakouska. Tyto jehlice ve skutečnosti nemají vrtaný otvor, protože ten vznikl již při odlévání. V některých případech je tato vnitřní dutina tak rozsáhlá, že skutečně připomíná dutou hlavici. Názorné př́klady tohoto výrobního procesu známe z Schneppenhausenu a z několika dalších neznámých lokalit v Hesensku (Kubach 1977a, 77-78, Taf. 3:42,45-47; Kubach 1977b, Abb. 10:10,15), dále z okolí Uelzenu v Dolním Sasku (Laux 1976, 47, Taf. 23:233), ale rovněž z pohřebiště v Gemeinlebarnu v Rakousku (Neugebauer 1994, Abb. 74:18). Kromě technologického hlediska se tyto jehlice odlišují od našich exemplářu i chronologicky.

K jehlicím ze Slezska má mnohem blíže celá skupina šatních spinadel ze západních oblastí střední Evropy. Jejich reprezentantem jsou hlavně jehlice typu Wollmesheim s kulovitou a někdy až dvojkónickou hlavicí a jedním až pěti vývalky na krčku, které se vyskytují v Bavorsku (např. Hennig 1970, Taf. 79:15,18), Bádensku-Württembersku (Jockenhövel 1971, 97, Taf. 11:124) a v největším počtu v Hesensku (Kubach 1977a, 422-436, Taf. A:1037,1059,1061,1075A; Taf. 67 až 71). Nejzápadnějš́i výskyt vyznačují nálezy ze střední Francie (Müller-Karpe 1980, Taf. 470E:1,3; 470H:2). Nejvýchodnější exemplář jehlice typu Wollmesheim pochází z hromadného nálezu v Rýdči v severních Čechách (Smolik 1885-86, 331; Kytlicová 2007, 29, 300-301, Taf. 85B:3) a poněkud odlišnější exemplář z depotu v Praze-Suchdolu (Zotz 1944, Abb. 48; Kytlicová 2007, 29, 296-297, Taf. 52C:1). Poměrně jednot- 


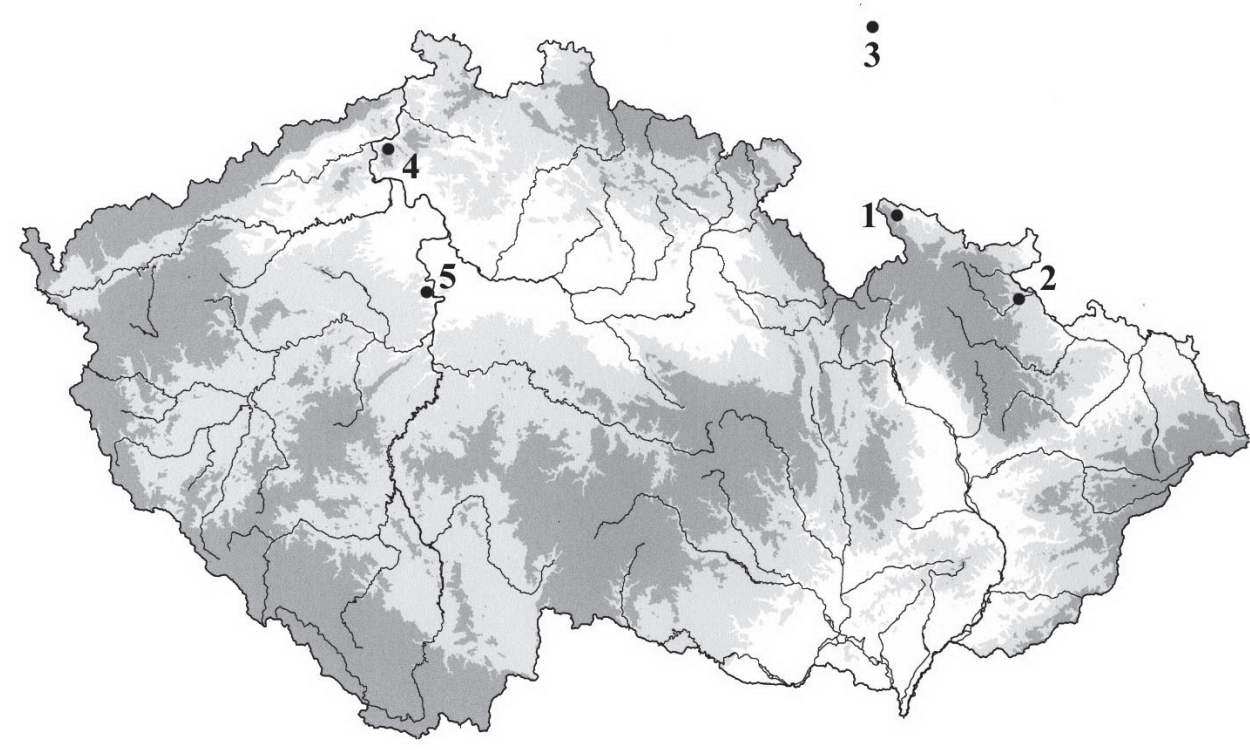

Obr. 3. Mapa rozšíření jehlic s dutou plechovou hlavicí (1 - Javorník, 2 - Krnov, 3 - neznámé naleziště v Dolním Slezsku) a jehlic typu Wollmesheim v Čechách (4 - Rydeč, 5 - Praha-Suchdol).

ný typ jehlice se podle tvaru hlavice, podle počtu vývalků nebo některých dalších odlišností (např. ve tvaru vývalků) dělí na celou řadu variant. Od našich slezských exemplářủ se liší hlavně tím, že jsou vesměs jednodílné a nemají hlavici plechovou, ale litou. Všechny varianty jehlic typu Wollmesheim považuje většina badatelů za vedoucí formu staršího a středního období popelnicových polí (Kimmig 1940, 106; Müller-Karpe 1959, Abb. 30:6; 31:3; Herrmann 1966, 30, Abb. 5:2730; Kubach 1977a, 439-466). Stejně datovala oba české exempláře z Prahy-Suchdolu a Rýdče O. Kytlicová, která je zařadila do horizontu depotů

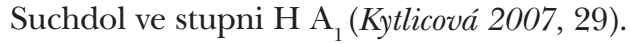

Jinou vzdáleně příbuznou skupinu představuje kolekce 14 jehlic skupiny M (groupe M épingles à tête spherique creuse) z jihovýchodní Francie. Tyto mají dutou kulovitou hlavici se dvěmi, třemi, čtyřmi, šesti nebo osmi otvory, které jsou někdy lemovány rytými kroužky, případně je výzdoba hlavice doplněna ještě skupi- nami jemných svislých rýh (Audouze - Courtois 1970, 32-33, pl. 9:223-236). Datovány jsou ve Francii do vrcholné doby bronzové III (Audouze - Courtois 1970, 33-34).

Samostatnou skupinu tvoří rovněž jehlice s bombovitou hlavicí (Bombenkopfnadeln nebo Bombennadeln) z Porýní, Hesenska (obr. 4:2; Kubach 1977a, 503, 506, Taf. 80: 1295-1297), Bavorska (Stroh 1955, 409, Abb. 1:10; Kaiser Kilian 1967, 53, Abb. 57), Lotrinska (Kubach $1977 a$, 503) a Švýcarska (Kubach 1977a, poznámka 29 na straně 505). Podle W. Kubacha (1977, 506, poznámka 32) patří k této skupině jehlic i některé exempláře východofrancouzské skupiny M (obr. 4:10; např. Audouze - Courtois 1970, Pl. 9: 235-236). Hlavice těchto jehlic jsou masivní, neobvyklé velké, protože jejich průměr může v některých případech překročit i $35 \mathrm{~mm}$ a jsou v nich obvykle tři nebo čtyři otvory. Tyto otvory jsou vesměs umístěny na největší výduti, ale v jednom prŕípadě po celé ploše hlavice. 

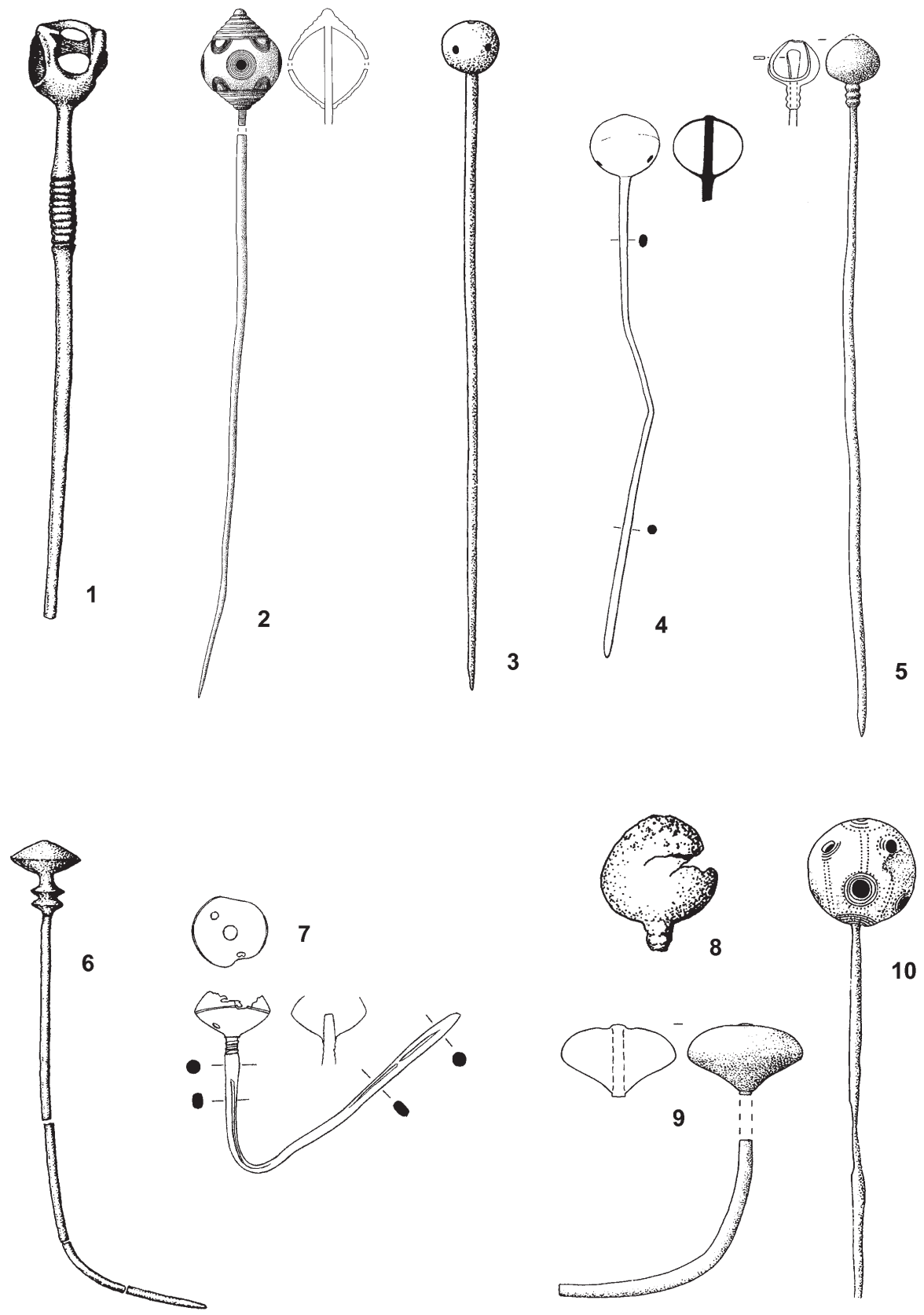

Obr. 4. Výběr jehlic s dutou kulovitou hlavicí ve střední Evropě. 1 - Libkovice, 2 - Mainz-Bretzenheim, 3 - Chen s/Léman, 4 - Krnov, 5 - Pfungstadt, 6 - Praha-Suchdol, 7 - Javorník, 8 - Rydeč, 9 - Bruchköbel, 10 - Thonon. Podle Kytlicová 2007 (1, 6, 8), Kubach 1977a (2, 5, 9), Audouze - Cortois 1940 (3, 10). 
Na rozdíl od jehlic typu Wollsmesheim jsou exempláře s bombovitou hlavicí datovány až do mladšího nebo pozdního stupně popelnicových polí (Müller-Karpe 1959, 215, Abb. 53:2; Kubach 1977a, 504-505, 507-508).

$\mathrm{K}$ jehlicím $\mathrm{s}$ bombovitou hlavicí má velmi blízko i značně početná a tvarově rozmanitá kategorie jehlic s vejčitou hlavicí, kterou známe od východní Francie přes Belgii, Švýcarsko a Německo (Müller-Karpe 1959, Taf. 166B:1,45; 170C:2; 170E:1; 193:1-4; Kubach 1977a, 498-502; Laux 1976, 92) až do střední Evropy (Durczewski 1939-1948, 323, Taf. XCIX:13; Šaldová 1965, 66; Říhouský 1965, 22, Taf. XXII:80e; Říhovský 1979, 182-188) a Karpatské kotliny (Řihovský 1983, 41-44). V západní části střední Evropy je někdy pro ně používán termín jehlice nákolního typu (Pfahlbaunadel), zatímco ve východní části střední Evropy jsou většinou označovány jako jehlice s cibulovitou hlavicí (Podborský 1970, 128-129). Obvykle jsou datovány do mladšího období popelnicových polí (MüllerKarpe 1959, Abb. 40:12; 41:13-14; 42:1-3; 53:2; Kubach 1977a, 495-498). O značné variabilitě těchto jehlic svědčí to, že občas je někteří badatelé řadí k bombovitým jehlicím, zatímco další je spojují s jehlicemi s vejčitou (případně cibulovou) hlavicí. $\mathrm{V}$ některých případech můžeme podle vyobrazení usuzovat, že snad jde o dvoudílné ozdoby (např. Kubach 1977a, Taf. 79:1274, 1277, 1279), zatímco u některých moravských

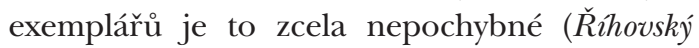
1965, Taf. XXII:80e; Řihouský 1979, 185; Taf. 56:1471-1473). Poprvé se můžeme s jehlicemi $\mathrm{s}$ cibulovitou hlavicí setkat nejdříve $\mathrm{v}$ mladším stupni popelnicových polí, tedy ve stupni HB (Podborský 1970, 129; Říhouský 1979, 186-187; Salaš 2005, 109). Na rozdíl od našich exemplářu nemají cibulovité jehlice dutou hlavici a pro klasifikaci slezských jehlic nemají žádný význam.

Naše jehlice se od výše uvedených spinadel liší v několika základních bodech. Exempláře z Javorníka, Krnova i z neznámé lokality v Dol- ním Slezsku nemají hlavici litou, ale zhotovenou z tenkého plechu (obr. 1; 2). Na rozdíl od jehlic typu Wollmesheim s hlavicí bez otvoru a s vývalky na krčku (obr. 4:5,8,9; Kubach 1977a, Taf. A:1037,1059,1061,1075A; 67-71) nemají naše exempláře vývalky a všechny tř́i mají po dvou otvorech, které jsou vždy umístěny na spodní straně hlavice. Liší se tím od jehlic s bombovitou hlavicí (obr. 4:2; Kubach 1977a, Taf. 80:1295,1297) a jehlic skupiny M z Francie (obr. 4:3,10; Audouze - Courtois 1970, pl. 9:223-235), které mají otvory na největší výduti a několikrát dokonce jsou tyto otvory rozloženy po celé ploše hlavice (Kubach 1977a, Taf. 80:1296; Audouze - Courtois 1970, pl.9:236). Všechny naše jehlice jsou dvojdíné, protože hlavice byla zhotovena samostatně z plechu a dodatečně nasazena na litou jehlu. U některých exemplářu typu Wollmesheim je velmi pravděpodobné, že jsou rovněž dvojdílné (např. Kubach 1977a, Taf. A:1037, 1059, 1061; 67:1005; 69:1037; 71:1075A, 1093), u dalších to můžeme jen s jistou pravděpodobností předpokládat. Absence otvorů v hlavici u jehlice typu Wolhesheim však potvrzuje, že jde o jiný typ jehlic.

Další odlišnost je zřetelná i v provedení jehly. Jehlice s bombovitou hlavicí, s vejčitou hlavicí, jehlice skupiny M nebo typu Wollmesheim, pokud to lze podle vyobrazení posoudit, mají jehlu kruhového průřezu. Masivní jehla exempláře z Javorníka má kruhový průřez jen těsně u hlavice a u hrotu, zatímco ve zbývající část jehly má řez ve tvaru obdélníka se zaoblenými hranami (obr. 1:1). Jehlice z neznámého naleziště v Dolním Slezsku má kruhový řez pouze ve spodní části masivní jehly (obr. 2a) a zbývající část má průřez rovněž ve tvaru obdélníka se zaoblenými hranami. Třetí jehlice z Krnova nemá jehlu tak masivní a její průřez je ve spodní části kruhový, zatímco průřez v horní polovině přechází od tvaru obdélníka se zaoblenými hranami až k oválnému řezu (obr. 1:2).

Exempláře z Javorníka, Krnova (obr. 1) a z neznámého slezského naleziště v blízkosti 
Wrocławi (obr. 2) patří k dosud neznámé samostatné skupině dvojdílných jehlic s plechovou, dutou a kulovitou hlavicí, která má na spodní straně dva menší otvory. Zatím je tato skupina reprezentována pouze třemi exempláři, které se našly ve Slezsku (obr. 3), z toho dvakrát v Horním Slezsku na českém území a jednou v Dolním Slezsku v Polsku. Vykazují sice určité vztahy k jehlicím typu Wollhesheim, jehlicím s bombovitou hlavicí, jehlicím skupiny M z Francie, případně k jehlicím s vejčitou (cibulovitou) hlavicí, ale nepochybně máme před sebou samostatnou a poměrně jednotnou skupinu.

Všechny tři jehlice pocházejí z ojedinělých nálezů a pro jejich datování nemáme žádné jednoznačné podklady. Nepřímým chronologickým důkazem je pouze místo nálezu krnovského exempláře na východním svahu výšinné polohy Burgberk (Přední cvilínský kopec). Toto naleziště bylo do literatury uvedeno již v sedmdesátých letech 19. století (Kulka 1886). V letech 1934-1935 zde prováděl terénní výzkum K. Schirmeisen, který prozkoumal 11 jam kultury nálevkovitých pohárů, ale fortifikaci datoval do mladší doby bronzové (Schirmeisen 1934, 76-77). Podle J. Nekvasila pochází z Burgberku převážně eneolitický materiál, několik střepů však patří do počátku středního stupně popelnicových polí a při zpracování lužických hradisek lokalitu zařadil do skupiny neověřených nebo mylně klasifikovaných lužických hradisek (Nekvasil 1982, 314, 327). Obdobně V. Dohnal, který naleziště umístil do katastrálního území Úvalna, což úředně platilo pouze do roku 1960, upozorňuje na nepočetné nálezy z pozdní doby bronzové, ale při klasifikaci opevnění se přiklonil spíše k eneolitickému datování (Dohnal 1988, 66-67). S chronologickým zařazením opevnění na Burgberku do eneolitu se v poslední době ztotožnil při zpracování lužického osídlení ve Slezsku i J. Juchelka $(2014,56)$. Bez ohledu na časovou klasifikaci opevnění sídliště na Burgberku jsou z lokality a blízkého okolí známy rovněž četné keramické i bronzové nálezy, které lze spojovat rámcově s kulturou lužických popelnicových polí (Salaš 2005, 434-435, Taf. 378A:1-7; Pavelková, 2011, 56-57; Juchelka 2014, 245-247; Bř́za - Sosín 2015, 182).

Bronzová jehlice z Javorníku je zatím prvním nálezem z doby bronzové v katastru obce. Z blízkého okolí obce zveřejnil J. Ř́hovský pouze hrot bronzového kopí z lokality Nový Dvůr (Ǩíhovský 1996, 92, Taf. 21:227). Podle J. Juchelky jde však o špatnou lokalizaci, protože předmět se údajně našel v Uhelné v místní části Nové Vilémovice (Juchelka 2014, 140, obr. 88:4). Tato dvě naleziště leží vzdušnou čarou od sebe přibližně 6-7 km. Kopí spojil J. Říhovský se starším úsekem popelnicových polí (Řihouský 1996, 93-94), zatímco J. Juchelka $(2014,272)$ ho řadí do stupně BD - HA . Další nálezy z okolí Javorníka pocházejí ještě z Bělé pod Pradědem a Skorošic (Juchelka 2014, 232, 267). Husté osídlení lužickou kulturou máme doloženo v blízkém okolí našich lokalit na polském území. Vedle rozsáhlého lužického pohřebiště v Kietrzu (Gedl 1989; Gedl 2000; k tomu další početná literatura) můžeme jmenovat z řady sídlišt např. lokality Koperniki, Lasowice nebo Paczkow a z pohřebišt aspoň Goraszowice (Gedl 1962).

Nový typ bronzové jehlice s velkou kulovitou dutou hlavicí můžeme tedy datovat pouze rámcově do mladší až pozdní doby bronzové. $\mathrm{S}$ ohledem na určitou podobnost s jehlicemi typu Wollmesheim se zdá poněkud pravděpodobnější jejich zařazení do mladší doby bronzové. S přesnější chronologickou klasifikací budeme muset patrně počkat až na případné další nalezené předměty se spolehlivějšími nálezovými okolnostmi ze sledované oikumeny. 
1) Za informaci o nálezu jehlice z Dolního Slezska děkuji Bc. M. Rychlému, pracovníkovi Vlastivědného muzea v Jeseníku. Jehlice byla zobrazena na polských detektorářských stránkách Odkrywca.pl ze dne 6. 8. 2011. Téma: ozdobna szpilka i inne przedmioty a jako autor byl uveden niechludow (2153/406).

2) Popis a přibližné rozměry jsou zpracovány na základě obrázku.

\section{Literatura}

Audouze, F. - Courtois, J.-C. 1970: Les Epingles du Sud-Est de la France. Prähistorische Bronzefunde XIII,1. München.

Břiza, S. - Sosín, L. 2015: Krnov (k. ú. Opavské Předměstí, okr. Bruntál). Přehled výzkumů 56-1, 182183.

Čtrnáct, V. 1961: Bronzový depot z Libákovic na Plzeňsku. Archeologické rozhledy XIII, 732-734.

Čujanová-Jilková, E. 1970: Mittelbronzezeitliche Hügelgräberfelder in Westböhmen. Archeologické studijní materiály 8.

Dohnal, V. 1988: Opevněná sídliště z doby popelnicových polí na Moravě. Studie muzea Kroměřížska '88.

Durczewski, Z. 1939-1948: Grupa górnośłąskomałopolska kultury łużyckiej w Polsce. Kraków.

Essen, R. 1985: Die Nadeln in Polen II (Mittlere Bronzezeit). Prähistorische Bronzefunde XIII, 9. München.

Gedl, M. 1962: Kultura łużycka na Górnym Śląsku. Wrocław - Warszawa - Kraków.

Gedl, M. 1983: Die Nadeln in Polen I (Frühe und ältere Bronzezeit). Prähistorische Bronzefunde XIII, 7. München.

Gedl, M. 1989: Groby z młodszego okresu epoki brązu na cmentarzysku w Kietrzu. Kraków.

Gedl, M. 2000: Das große Gräberfeld aus der Bronze- und Früheisenzeit in Kietrz (Oberschlesien). Jahresschrift für mitteldeutsche Vorgeschichte 83, 69-108.

Hennig, H. 1970: Die Grab- und Hortfunde der Urnenfelderkultur aus Ober- und Mittelfranken. Kallmünz/Opf.

Herrmann, F.-R. 1966: Die Funde der Urnenfelderkultur in Mittel- und Südhessen. Berlin.

Jockenhövel, A. 1971: Rasiermesser in Mitteleuropa. Prähistorische Bronzefunde VIII, 1. München.
Juchelka, J. 2014: Lužická kultura v českém Slezsku. Brno.

Kaiser, K. - Kilian, L. 1967: Fundberichte aus der Pfalz für die Jahre 1953-1955. Mitteilungen des historischen Vereins der Pfalz 65. 5-153.

Kimmig, W. 1940: Die Urnenfelderkultur in Baden untersucht auf Gräberfunde. Römisch-Germanische Forschungen 14. Berlin.

Kubach, W. 1977a: Die Nadeln in Hessen und Rheinhessen. Prähistorische Bronzefunde XIII, 3. München.

Kubach, W. 1977b: Zum Beginn der bronzezeitlichen Hügelgräberkultur in Süddeutschland. Jahresbericht des Instituts für Vorgeschichte der Universität Frankfurt a. M. München.

Kulka, R. 1886: Der Burgberg bei Jägerndorf in Schlesien. Mitteilungen der Anthropologischen Gesellschaft in Wien XVI, 169-174.

Kytlicová, O. 2007: Jungbronzezeitliche Hortfunde in Böhmen. Prähistorische Bronzefunde XX, 12. Stuttgart.

Laux, F. 1976: Die Nadeln in Niedersachsen, Prähistorische Bronzefunde XIII, 1. München.

Müller-Karpe, H. 1959: Beiträge zur Chronologie der Urnenfelderzeit nördlich und südlich der Alpen. Berlin.

Müller-Karpe, H. 1980: Handbuch der Vorgeschichte IV - Bronzezeit. München.

Nekvasil, J. 1982: Bemerkungen zu den Burgwällen der Lausitzer Kultur in Mähren. In: Beiträge zum bronzezeitlichen Burgenbau in Mitteleuropa. Berlin - Nitra, 311-330.

Neugebauer, J.-W. 1994: Bronzezeit in Ostösterreich. St. Pölten - Wien.

Pavelková, M. 2011: Archeologické nálezy z období lužických popelnicových polí na Krnovsku. Rkp. diplomové práce uložené na Slezské univerzitě v Opavě. 
Podborský, V. 1970: Mähren in der Spätbronzezeit und an der Schwelle der Eisenzeit. Brno.

Rychlý, M. - Stuchlik, S. 2016: Javorník (k. ú. Bílý Potok, okr. Jeseník), Přehled výzkumů 57-1, 210.

Řihovský, J. 1965: Das Urnengräberfeld von Klenotnice, Fontes Archaeologici Pragenses 8, Pragae.

Řihouský, J. 1979: Die Nadeln in Mähren und im Ostalpengebiet (von der mittleren Bronzezeit bis zur älteren Eisenzeit). Prähistorische Bronzefunde XIII, 5. München.

Řihouský, J. 1983: Die Nadeln in Westungarn. Prähistorische Bronzefunde XIII, 10. München.

Řihovský, J. 1996: Die Lanzen-, Speer- und Pfeilspitzen in Mähren, Prähistorische Bronzefunde V, 2. Stuttgart.
Salaš, M. 2005: Bronzové depoty střední až pozdní doby bronzové na Moravě a ve Slezsku. Brno.

Schirmeisen, K. 1934: Jungsteinzeitliche Siedlungen auf Burgberg bei Jägerndorf. Sudeta X, 68-77.

Smolik, J. 1885-86: Pozůstalost potulného obchodníka z doby předhistorické, Památky archeologické a místopisné XIII, 331-333.

Stroh, A. 1955: Neue Baggerfunde aus der Donau bei Regensburg, Germania 33, 407-410.

Šaldová, V. 1965: Západní Čechy v pozdní době bronzové. Pohřebiště Nynice I. Památky archeologické LVI, 1-90.

Zotz, L. 1944: Von den Mammutenjägern zu den Wikingen. Leipzig. 


\section{A new type of bronze pin in Silesia}

In the past few years, three new bronze pins were found in Silesia with the help of metal detectors. The finds come from Javorník-Bílý Potok (Fig. 1:1; Rychlý - Stuchlik 2016, 210, obr. 5), Krnov-Burgberk (Fig. 1:2; Bř́za - Sosin 2015) and from an unknown findspot in close vicinity of Wrocław (Fig. 2). All three specimens are two-part pins with large hollow spherical head with two small holes at its bottom. It is a quite new pin type, which is known so far only from Silesia - two pieces from Czech and one piece from Polish territory (Fig. 3). A remote analogy to our finds is represented by pins of Wollmesheim type, which are known in large quantities from Germany and in two specimens from Bohemia, namely from Prague-Suchdol and Rydeč (Kytlicová 2007, 29, 296-297, 300-301, Taf. 52C:1; 85B:3). These pins, which also have a hollow head, but never with perforations, are dated to the Late Bronze Age (Kimmig 1940, 106; Kubach 1977a, 439-466). Another analogy is represented by pins of group $\mathrm{M}$ from south-eastern France, which fall within the advanced Bronze Age (Audouze - Courtois 1970, 33-34). Similar forms are also found among globular-headed pins from Germany and Switzerland, which occur in the Final Bronze Age (Müller-Karpe 1959, 215, Abb. 53:2; Kubach 1977a, 504-505, 507-508). The three new pieces from Silesia, however, form a separate group, which differs from the above-mentioned pins by their sheet metal head, two holes in the bottom part of the head, and the shape of the needle. All three pins are isolated finds and we do yet have sufficient support to their dating. A general dating to the Urnfield Period is only indicated by the finding place on the slope below the hilltop settlement of Krnov-Burgberk. Certain similarity with Wollmesheim-type pins could probably indicate a dating to the Late Bronze Age. The chronological position of our specimens, however, will not be determined with certainty until we find another pins of this type in reliable find contexts. 


\section{Stanislav Stuchlík}

- Ústav archeologie, Filozoficko-přírodovědecká

fakulta, Slezská univerzita v Opavě

Masarykova třída 343/37, 74601 Opava

s.stuchlik@seznam.cz 